\title{
WHIRL WIND DETECTION AND IDENTIFICATION IN INDONESIA UTILIZING SINGLE POLARIZATION DOPPLER WEATHER RADAR VOLUMETRIC DATA
}

\author{
Abdullah Ali ${ }^{\text {a,b }}$, Sabitul Hidayati ${ }^{\text {a,b }}$ \\ a Indonesia State College of Meteorology Climatology and Geophysics (STMKG) Jakarta - alibinakhsan@gmail.com \\ b Indonesia Agency for Meteorology Climatology and Geophysics - sabitul.hidayati@gmail.com
}

KEY WORDS: whirl wind, remote sensing, weather radar, radial velocity, reflectivity, spectral width

\begin{abstract}
:
Whirl wind occurrence frequency in Indonesia tends increasing in the last five years. Geospatial data from National Agency for Disaster Management (BNPB) recorded 72 cases with the impact of the two victims died, ten injured, 485 people were evacuated, and 1285 buildings were destroyed at period of January-June 2015. Based on the impact, early warning through remote sensing by using single polarization Doppler weather radar is need to be efforted. Whirl wind detection is done by identifying the characteristic pattern of the rotating convective cloud system by hook echo, analyzing the exsistance of vortex and rotation, and the strength of turbulence. The results show horizontal wind profile with a rotational pattern at CAPPI (V) and HWIND (V) by the altitude of 0.5 $\mathrm{km}$, strong turbulence through product CAPPI (W) $0.5 \mathrm{~km}$ ranged of $1.75-2.05 \mathrm{~ms}-1$, the vertical wind profile by product VVP (V) with a maximum value updraft reaches more than 20 knots at a 100-200 meters height, strong horizontal wind shear through HSHEAR (V) and CAPPI (HSHEAR) altitude of $0.5 \mathrm{~km}$ with a range of 6.23 to $10.12 \mathrm{~ms}-1 / \mathrm{km}$. SWI and SSA show that the cloud base height is very low ranged from 200-600 meters with a maximum reflectivity reached $61.5 \mathrm{dBZ}$ by top cloud height reached 14 $\mathrm{km}$, while the product CAPPI $(\mathrm{Z}) 0.5 \mathrm{~km}$ and CMAX $(\mathrm{Z})$ is very difficult to identify patterns hook echo. The results of remote sensing are very representative with the physical properties of whirl wind even whirl wind in a smaller scale.
\end{abstract}

\section{PRELIMINARY}

Whirl wind occurrence in Indonesia with increasing frequency for the last five years led to a very significant impact to the environment damage from building collapse till the victim died. Meteorological instruction in Head of Indonesian Agency for Meteorology Climatology and Geophysics Rules No. KEP.009 in 2010 stated that the whirl wind was a strong wind that spun out of the clouds Cumulonimbus $(\mathrm{Cb})$ at speeds in excess of $34.8 \mathrm{knots}$, or $64.6 \mathrm{~km} / \mathrm{h}$ within a short duration. Another understanding from other references mentioned that the whirl wind is the spinning wind formed under the direction of convective clouds in a developing stages due to the vortex/stretched helical rising air by vertical motion (updraft) below the cloud (Wirdjohamidjojo, 2010). Studies for the whirl wind detection can be associated with the incidence of tornado that often occur in the America with smaller spatial scales and shorter temporal scale (Redha, 2014). Meteorological instrumentation owned by BMKG under the capability if high spatial and temporal resolution that can detect whirl wind occurrence is single polarization Doppler weather radar.

There are two classifications of storm cells cause whirl wind, namely supercell storm and non-supercell storm. The research from Pryzbylinski at 1995 states that non-supercell whirl windes associated with patterns of Tornado Vortex Signature (TVS) by the radial velocity product and cloud formations patterns which have evolved into a hook or bow echo (Pryzbylinski, 1995). Hook echo pattern that detected through the reflectivity at radar imagery indicates supercell storm system, besides mesocyclone pattern by the radial velocity product (Smith, 1996; Brown, 1977). Hook echo is a cloud patterns detected by weather radar with very high reflectivity values and the formation of a pattern that resembles a hook (Wakimoto, 1992). While the bow echo pattern is a pattern of a cluster of clouds Cumulonimbus elongated and can develop to the hook echo pattern (Davis, 2004). Area rotating head / comma head and the front edge (leading edge) is the most potential area for suppercell or non-supercell whirl wind (Novak, 2009). Rotational wind profile caused by whirl windrelated to the turbulence severity at the center of the vortex and the surrounding locations. Detection of turbulence intensity can be done through the analysis of products with a moment of spectral width (Bohne, 1982). But there is a limitation where the value of spectral width on Doppler weather radar is less representative for estimating the intensity of turbulence on radar targets farther than $200 \mathrm{~km}$ (Fang, 2001). Some remote sensing and identification of whirl wind events in Indonesia have been conducted using BMKG weather radar network by adopting a supercell whirl wind analysis techniques. Whirl wind occurence in Sidrap February 24, 2012 shows the hook echo pattern detected on radar images with a maximum reflectivity value at 53 DBZ (Abubakar, 2013). While in Sidoarjo December 26, 2012 also showed a hook echo pattern (Ayudia, 2012). Results of the analysis of the case of the whirl wind in Pankep January 12, 2013 provide the information of mesocyclone pattern detected by CAPPI (V) at an altitude of $0.5 \mathrm{~km}$ and $1 \mathrm{~km}$ (Fikroh, 2013). Analysis conducted by the BMKG Remote Sensing Division on whirl wind occurrences in Kuta, Denpasar dated March 17, 2012 shows a pattern of bow echo on the radar images that are identical to $\neg$ non-supercell whirl wind. While the results of research by Redha 2014 in South Sumatera by taking six case of studies, not all show the hook echo pattern and bow echo, only four incidents showed a pattern hook echo (Redha, 2014).

Whirl wind detection method by adopting seupercell whirl wind detection techniques on some of the results of the analysis show the characteristic patterns of cloud detected on radar, reflectivity values, and wind patterns at the time the whirl wind occur. The characteristic is different from the characteristic tornado events in America. The characteristic distinction becomes important to 
be investigated as the main duty of BMKG which has a fundamental duty as a center of information and early warning for extreme weather events including whirl wind. The aim of this study is knowing the ability of BMKG weather radar network to perform the remote sensing for the whirlwind of occurrence in Indonesia and then analyze the characteristics through products with moments of reflectivity, radial velocity and spectral width. Characteristics obtained are expected to be used as a parameter of decision-making for early warning of whirl wind events in Indonesia which can then be disseminated to the public and relevant agencies.

\section{DATA AND METHOD}

\subsection{Data}

The location of whirl wind occurrence were taken from geospatial data for whirl wind events provided by National Agency for Disaster Mitigation Management (BNPB) that can be accessed through http://geospasial.bnpb.go.id/pantauanbencana/data/datatopan.ph p. Based on the availability of data owned by the author, it is determined seven whirl wind incident as a case study in three locations those are whirl wind occurence in Lampung, Bali, and Surabaya. Details coordinates of the location and time of occurrence shown in Table 1.

\begin{tabular}{|c|c|c|}
\hline No & Location & $\begin{array}{c}\text { Time } \\
\text { Occurrence }\end{array}$ \\
\hline 1 & $\begin{array}{l}\text { Pringsewu District; Lampung } \\
\text { Province } \\
\left(5.354^{\circ} \mathrm{LS} 105.041^{\circ} \mathrm{BT}\right)\end{array}$ & $\begin{array}{l}\text { 2014-01-06 } \\
(14: 00 \text { LT) }\end{array}$ \\
\hline 2 & $\begin{array}{l}\text { Labuhan Ratu } \\
\text { District;;Lampung Province } \\
\left(5.134^{\circ} \mathrm{LS} 105.665^{\circ} \mathrm{BT}\right)\end{array}$ & $\begin{array}{l}\text { 2014-01- } \\
06(16: 30 \text { LT })\end{array}$ \\
\hline 3 & $\begin{array}{l}\text { Pringsewu District; Lampung } \\
\text { Province } \\
\left(5.330^{\circ} \mathrm{LS} 104.886^{\circ} \mathrm{BT}\right)\end{array}$ & $\begin{array}{l}\text { 2014-01- } \\
\text { 08(17:00 LT) }\end{array}$ \\
\hline 4 & $\begin{array}{l}\text { Bangli Sub District; Bali } \\
\text { Province } \\
\text { (S8.2653 E1 14.9604) }\end{array}$ & $\begin{array}{l}\text { 2015-03- } \\
\text { 10(17.00 LT) }\end{array}$ \\
\hline 5 & $\begin{array}{l}\text { Pasuruan District ;East Java } \\
\text { Province } \\
\left(7.644^{\circ} \mathrm{LS} 112.903^{\circ} \mathrm{BT}\right)\end{array}$ & $\begin{array}{l}2013-11-26 \\
(15.00 \mathrm{LT})\end{array}$ \\
\hline 6 & $\begin{array}{l}\text { Sidoarjo District East Java } \\
\text { Province } \\
\left(7.351^{\circ} \mathrm{LS} 112.769^{\circ} \mathrm{BT}\right)\end{array}$ & $\begin{array}{l}\text { 2014-03- } \\
09(16: 00 \text { LT })\end{array}$ \\
\hline 7 & $\begin{array}{l}\text { Gresik District; East Java } \\
\text { Province } \\
\left(112.713^{\circ} \mathrm{LS} 7.229^{\circ} \mathrm{BT}\right)\end{array}$ & $\begin{array}{l}\text { 2014-02- } \\
20(17.00 \text { LT })\end{array}$ \\
\hline
\end{tabular}

Table 1. Details whirl wind occurence

The data used in this study is the volumetric data from Doppler weather radar C-band Meteorology Station Juanda (Gematronik Radar), Raden Inten Meteorology Station Bandar Lampung (EEC Radar), and BBMKG Region III Denpasar (EEC Radar). Moment used is the reflectivity, radial velocity and spectral width with a temporal resolution of 10 minutes.

\subsection{Methods}

Descriptive method is used in this research, consist of data processing, analyzing, and interpret weather radar imagery for determining the pattern cathced from reflectivity, radial velocity, and spectral width product for whirl wind events that occurred in Indonesia.

The methodology used in this study are:

1. Volumetric data processing from single polarization Doppler weather radar at Raden Inten Bandar Lampung Meteorological Station and BBMKG Region III Denpasar using Edge 5.0 applications while the data from Juanda Meteorological Station processed by using RainRCC application version 5.29.5 to generate products with a moment of reflectivity $(\mathrm{Z})$, radial velocity $(\mathrm{V})$, and spectral width (W).

2. Quantitative and qualitative analysis of each whirl wind occurence is done through some products, those are CMAX (Z) for maximum reflectivity value analysis and cloud patterns, CAPPI $(\mathrm{Z}, \mathrm{V}, \mathrm{W})$ altitude of $0.5 \mathrm{~km}$ and $1 \mathrm{~km}$ for the analysis of wind profile horizontal, rotation detection, and intensity of turbulence in the cloud related to the whirl wind, product VVP $(\mathrm{V})$ for analysis provil vertical wind and the value of the divergence, product CAPPI(VSHEAR, HSHEAR) in EEC Radar and HSHEAR / VSHEAR (V) in Gematronik to great analysis gisir wind (shear) horizontally and vertically, product SWI in Radar Gematronuk Radar, Strom Track, and SSA on EEC Radar for structural analysis of storm clouds and cloud core, as well as products ETOP and EBASE on EEC Radar to see the height of the base and the height of the peak cloud,

3. Characterizing quantitative and qualitative value in each case study.

\section{RESULTS AND ANALYSIS}

Details product analyzed at each occurrence whirl wind contained in Appendix 1.

\section{Whirl wind Pringsewu Lampung Province, January 6, 2014}

Whirl wind occurred in the Tegal Agung and Tulung Gading Rejo Village at the point of coordinates $1050415,354^{\circ} \mathrm{S} 14^{\circ}$ E causing 14 houses slightly damaged in the village Tulung and 6 houses lightly damaged in the village of Tegal. Results of volumetric data processing at the time of the incident at 14:00 pm or 07:00 UTC attached in Figure 1.

CAPPI(V) $0.5 \mathrm{~km}$ and $1 \mathrm{~km}$ product analysis indicate a rotation with two radial velocity echo in the opposite direction and separated by zero isodop. The maximum value is 10.6 knots outbound and 10.2 knots for inbound. Rotation in the bottom layer becomes the initial indication for whirl wind events. CAPPI (W) at an altitude of $1 \mathrm{~km}$ in the location of events has a maximum value of $3.0 \mathrm{~ms}^{-1}$ and at an altitude of $0.5 \mathrm{~km}$ worth $2.0 \mathrm{~ms}^{-1}$. Based on the classification of spectral width value of a particular phenomenon in research of Fang at 2001, the value falls within the category of multi-cell severe storm with very strong turbulence. The classification results verified by CMAX $(\mathrm{Z})$, which indicate the presence of multi cells storm clouds with maximum reflectivity value of $58 \mathrm{dBZ}$.

Bow echo or hook pattern was not observed in the reflectivity echo. Cloud base height of $0.3 \mathrm{~km}$ on the products listed in EBASE product and high cloud tops found $9.9 \mathrm{~km}$ on ETOPS product. CAPPI (VSHEAR) $1 \mathrm{~km}$ at the location of $5.2675^{\circ} \mathrm{S}$ $105.0359^{\circ} \mathrm{E}$ shows the value of vertical shear is 79.2 knots / $\mathrm{nmi}\left(21.38 \mathrm{~ms}^{-1} / \mathrm{km}\right)$ and near the site at coordinates $5.2665^{\circ} \mathrm{S}$ 
$105.0365^{\circ} \mathrm{E}$ has the value in the opposite dirrection of -32.4 knots / nmi $\left(8.7 \mathrm{~ms}^{-1} / \mathrm{km}\right)$. Positive values indicate the vertical wind shear for the current updraft and a negative value indicates the vertical wind shear for the current downdraft. Two wind current in the opposite direction to the adjacent spot shows the instability of the air mass due to the rotation and strong turbulence. The maximum value of horizontal wind shear at an altitude of $1 \mathrm{~km}$ through CAPPI (HSHEAR) is 79.2 knots / nmi $\left(2.38 \mathrm{~ms}^{-1} / \mathrm{km}\right)$ at the location of $5.2540^{\circ} \mathrm{S} 105.0280{ }^{\circ} \mathrm{E}$. Strong horizontal wind shear indicates the instability of the horizontal wind profile and will affect the life span of a storm cell. VVP product shows the dominance of downdraft on the layer below $2 \mathrm{~km}$ by the maximum value of $29 \mathrm{~m} / \mathrm{s}$. Divergences in the layer $1 \mathrm{~km}$ worth $-1170 \times 10^{-4} \mathrm{~s}^{-1}$, where negative values indicate a convergence in the layer. Stromtrack products and SSA indicates core cell of cloud at an altitude of $0.48 \mathrm{~km}$ with a maximum reflectivity value of $47.5 \mathrm{DBZ}$.

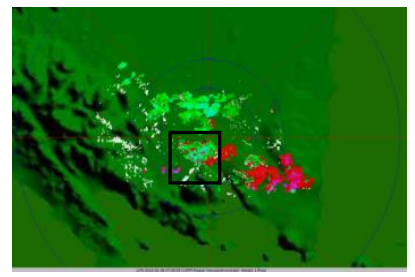

CAPPI(V) $1 \mathrm{KM}$

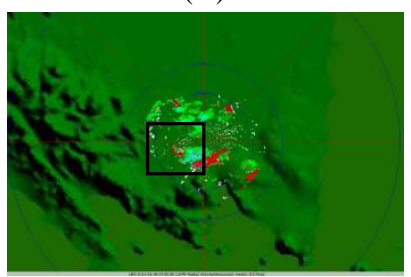

CAPPI(V) $0.5 \mathrm{KM}$

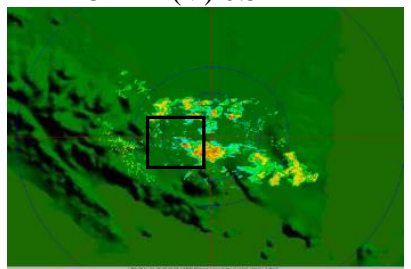

CAPPI (Z) 1 KM

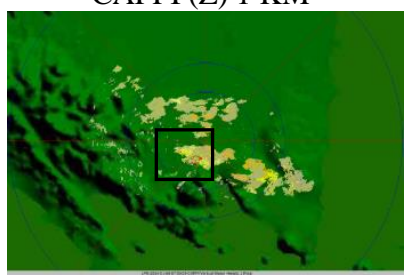

CAPPI(VSHEAR) 1KM

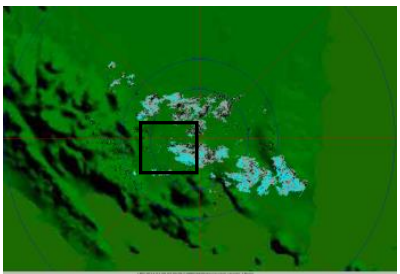

CAPPI (W) 1 KM

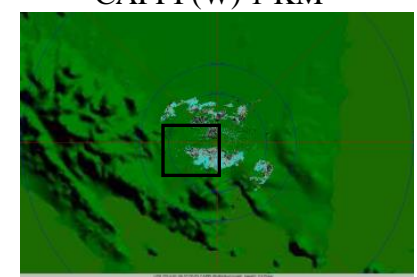

CAPPI (W) $0.5 \mathrm{KM}$

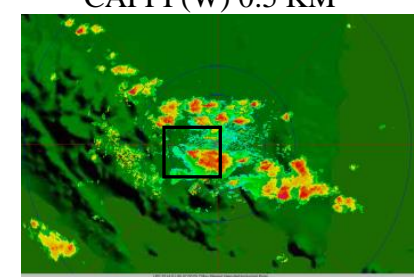

$\operatorname{CMAX}(\mathrm{Z})$

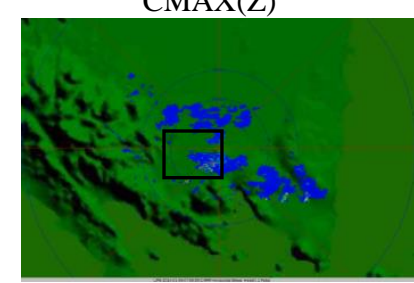

CAPPI(HSHEAR) 1KM
Figure 1. Radar product at whirl wind occurence in Pringsewu Distrcit, Lampung Province, January 6, 2014

\section{Whirl wind East Lampung District January 6, 2014}

Whirl wind occurred in the Rajabasa Labuhan village of Lama sub-district at $5.134{ }^{\circ} \mathrm{S} 105665^{\circ} \mathrm{E}$ coordinates causing two houses were severely damaged and five houses were slightly damaged. Results of volumetric data processing at the time of the incident at $16.30 \mathrm{pm}$ or 9:30 UTC attached in Figure 2. Wind rotation is detected by CAPPI product (V) $1 \mathrm{~km}$ with a maximum value of 12.8 knots outbound and inbound maximum of 8.6 knots. Strong turbulence indicated by the value through product CAPPI (W) $1 \mathrm{~km}$ to the value of $2.7 \mathrm{~ms}^{-1}$. Multicellstorm category based on research of Fang 2001 on the value of the spectral width is verified through CMAX $(\mathrm{Z})$ which shows cluster of clouds set up a multi-cell pattern with a bow echo by the maximum reflectivity value of $58 \mathrm{dBZ}$.

Cloud base detected through EBASE product set of $0.9 \mathrm{~km}$ and carrying cloud tops at an altitude of $16.2 \mathrm{~km}$ through ETOPS products. Vertical wind shear through product CAPPI (VSHEAR) $1 \mathrm{~km}$ are not too significant with a value of $13.5 \mathrm{~ms}^{-}$ $1 / \mathrm{km}$ on the location of $4.9225^{\circ} \mathrm{S} 105.7270^{\circ} \mathrm{E}$ and values of vertical wind shear arround these points tend to be uniform without any negative values. Strong scale horizontal wind shear detected by CAPPI (HSHEAR) products $1 \mathrm{~km}$ altitude by the value of $55 \mathrm{~ms}^{-1} / \mathrm{km}$. VPP product verifies the rotation through the wind profile in the coat of $1-2 \mathrm{~km}$ with a very significant change in direction. The surface layer up to $1 \mathrm{~km}$ was dominated by the downdraft current with a maximum value of $40 \mathrm{~ms}^{-1}$ and at an altitude of $1-3 \mathrm{~km}$ maximum downdraft value recorded $78 \mathrm{~ms}^{-1}$. Strong vertical shear values are also verified through VVP product. Divergences in the surface layer shows the value $-0134 \times 10-4 \mathrm{~s}^{-1}$ (convergence) and at $0.2 \mathrm{~km}$ layer showed a positive value of $0468 \times 10^{-4} \mathrm{~s}^{-1}$ (divergent). Divergence value at the opposite to the adjacent layers indicates rotation in the layer. Divergence value on a layer $1.5-2 \mathrm{~km}$ also shows the numerical opposite value by $-2624 \times 10^{-4} \mathrm{~s}^{-1}$ (convergence) at layer $2 \mathrm{~km} 0.190 \times 10^{-4} \mathrm{~s}^{-1}$ (divergent) in the layer $1.5 \mathrm{~km}$.

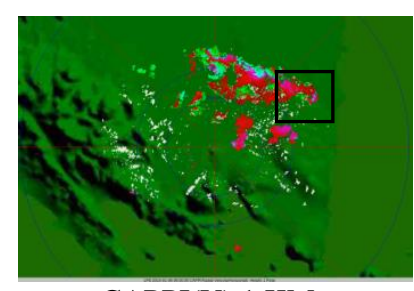

CAPPI(V) $1 \mathrm{KM}$

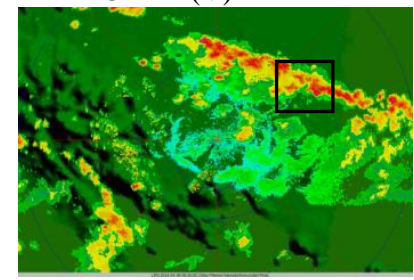

$\operatorname{CMAX}(\mathrm{Z})$

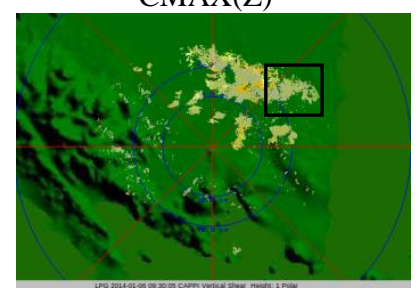

CAPPI(VSHEAR) 1KM

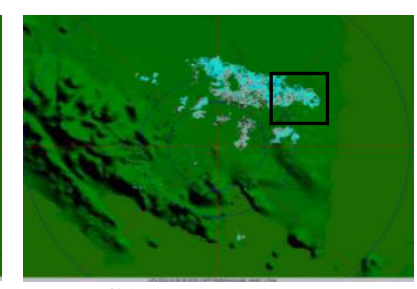

CAPPI (W) $1 \mathrm{KM}$

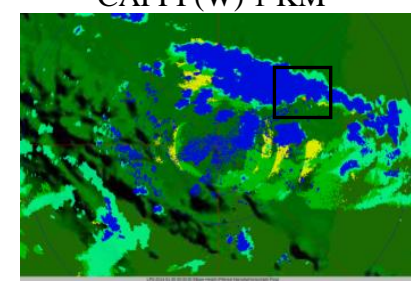

EBASE

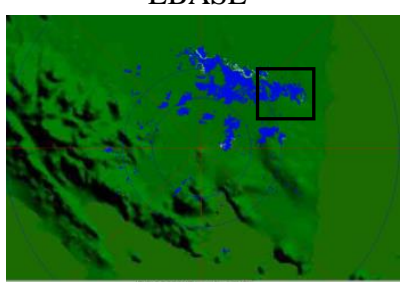

CAPPI(HSHEAR) 1KM
Figure 2. Radar product at whirl wind occurence in East Lampung District, January 6, 2014

Whirl wind Pringsewu District, Lampung Proveince, January 8, 2014

Whirl wind occurred in the Pekon Fajar Baru village of Pagelaran District at coordinate of $104886^{\circ} \mathrm{S} 5,330^{\circ} \mathrm{E}$ causing the damage to five houses slightly damaged, schools, and 700 rubber trees collapsed. Results of volumetric data processing at 
the time of the incident at $17.00 \mathrm{LT}$ or 10.00 UTC attached in Figure 3. The observation of the weather radar does not show the existence of convective clouds on the location and time specified by BNPB.

After reviewing further, at $09 \mathrm{UTC}$ or $16.00 \mathrm{LT}$, weather radar observe the reflectivity echo through $\operatorname{CMAX}(\mathrm{Z})$ with a bow echo pattern and evolve into a comma echo at one of the leading edge with maximum $\mathrm{Z}$ value reached $60 \mathrm{dBZ}$. Horizontal wind profile at the time showed a cyclonic rotation echo through product CAPPI (V) $1 \mathrm{~km}$. Maximum values reach 13 knots outbound and 12.6 knots inbound. Wind rotation in the lower layers is also indicated on the product CAPPI (V) $0.5 \mathrm{~km}$ with a maximum value of 13.2 knots outbound and 13.2 knots inbound.

Strong lability caused by the rotation cause turbulence with strong intensity detected by CAPPI(W) $1 \mathrm{~km}$ that is worth 2.5 $\mathrm{ms}^{-1}$. Horizontal wind shear were observed reaching $96.5 \mathrm{~ms}^{-}$ ${ }^{1} / \mathrm{km}$ on the location of $5.3365^{\circ} \mathrm{S} 105.0632{ }^{\circ} \mathrm{E}$ through product CAPPI (HSEHAR) $0.5 \mathrm{~km}$. Those horizontal wind shear indicates the direction and speed fluctuations are very significant and strengthen the results of the rotation analysis. While the value of vertical wind shear has two opposite direction those are $-51 \mathrm{~ms}^{-1} / \mathrm{km}$ at coordinates $5.3427{ }^{\circ} \mathrm{S}$ and $31{ }^{\circ} \mathrm{E} 105055 \mathrm{~ms}^{-1} / \mathrm{km}$ at coordinates $5.3381{ }^{\circ} \mathrm{S} 105.0565{ }^{\circ} \mathrm{E}$. Vertical shear in the opposite direction will strengthen the convective system clouds and turbulence strength. The horizontal wind profile at VVP products showed a significant change in direction between surface layers adjacent to a height of $2 \mathrm{~km}$.
CAPPI(V) $0.5 \mathrm{KM}$

CAPPI (Z) 1 KM

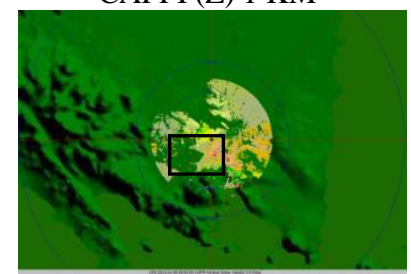

CAPPI(VSHEAR) $1 \mathrm{KM}$
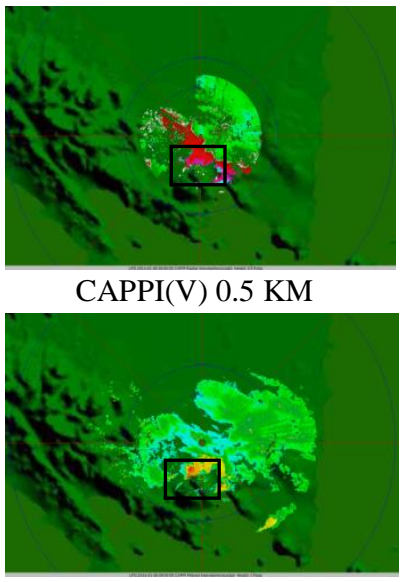

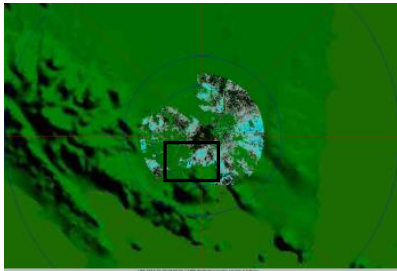

CAPPI (W) $0.5 \mathrm{KM}$

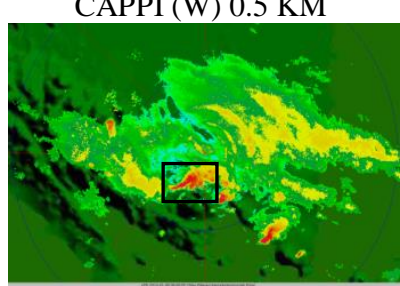

$\operatorname{CMAX}(\mathrm{Z})$

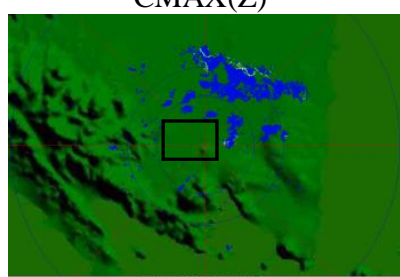

CAPPI(HSHEAR) $0.5 \mathrm{KM}$
Figure 3. Radar product at whirl wind occurence in Pringsewu District, Lampung Proveince, January 8, 2014

Description of the vertical wind profile VVP strengthen product analysis of CAPPI (VSHEAR) which indicates a strong vertical wind shear. At the surface layer until a layer of $1.2 \mathrm{~km}$ was dominated by updraft flow with a maximum value $21 \mathrm{~ms}^{-1}$. At an altitude of $2 \mathrm{~km}$ downdraft is detected with a value of $29 \mathrm{~ms}^{-}$ 1. Updraft flow dominated from layer $2-3 \mathrm{~km}$.
Divergences in the lining of 1000 meters worth $-1429 \times 10^{-4} \mathrm{~s}^{-1}$ (convergent) and in the surface layers of $0089 \times 10-4 \mathrm{~s}-1$ (divergent). The divergent and convergent on the adjacent layers that observed by CAPPI(HSHEAR) shows strong horizontal wind shear. Storm cloud structure has a height of 0.3 $\mathrm{km}$ on EBASE and $8.9 \mathrm{~km}$ high cloud tops ETOPS products. Stromtrack products and SSA describe cloud core nucleus with maximum reflectivity value $47.5 \mathrm{dBZ}$ at an altitude of $0.48 \mathrm{~km}$.

\section{Whirl wind Pasuruan, November 26, 2013}

Whirl wind occurred in the village of Gersian and Ngayunan, Beji Sub District, Pasuruan District of East Java Province at the coordinates of $7.644^{\circ} \mathrm{S} 112903^{\circ} \mathrm{E}$. Results of volumetric data processing in this case contained in Figure 4.

Rotation wind is detected through CAPPI (V) $0.5 \mathrm{~km}$ by mesocyclone pattern with $6.52 \mathrm{~ms}^{-1}$ maximum outbound and $7.37 \mathrm{~ms}^{-1}$ of maximum inbound. HWIND product showed a similar pattern of rotation at an altitude of $0.5 \mathrm{~km}$ and $1 \mathrm{~km}$. Analysis of the products CAPPI (W) at an altitude of $1 \mathrm{~km}$ and $0.5 \mathrm{~km}$ indicate the occurrence of turbulence and strong turbulence scale with the value of the spectral width reaches $2.08 \mathrm{~ms}^{-1}$ and $2.24 \mathrm{~ms}^{-1}$ for each height.
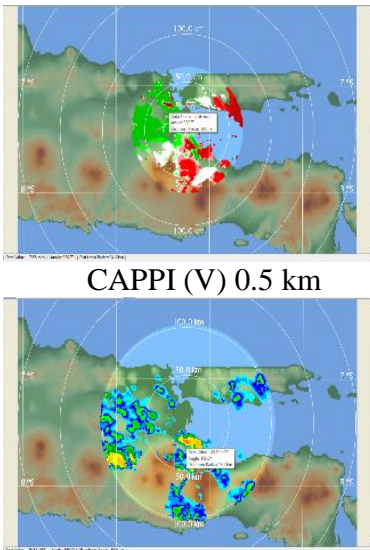

CAPPI (Z) $1 \mathrm{~km}$

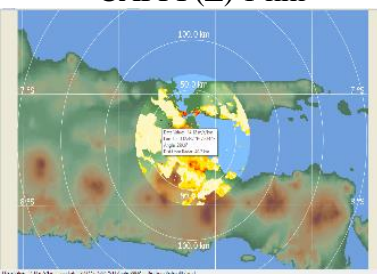

HSHEAR (V) $0.5 \mathrm{~km}$

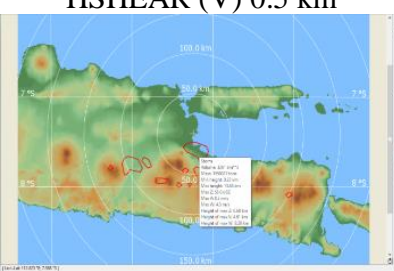

SWI (Storm)

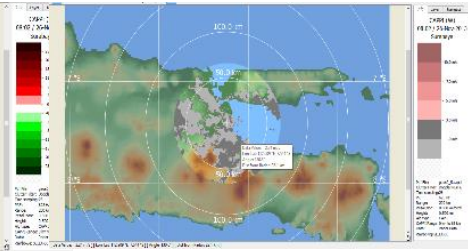

CAPPI (W) $0.5 \mathrm{~km}$

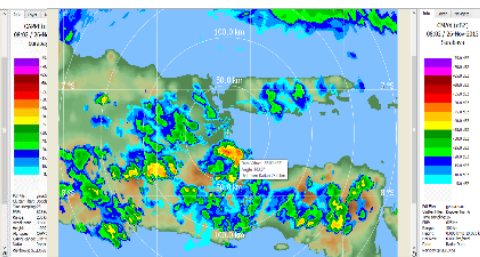

$\operatorname{CMAX}(Z)$

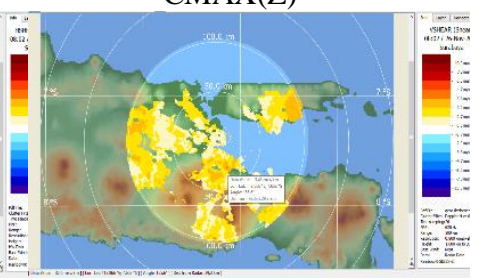

VSHEAR (V) $0.5 \mathrm{~km}$

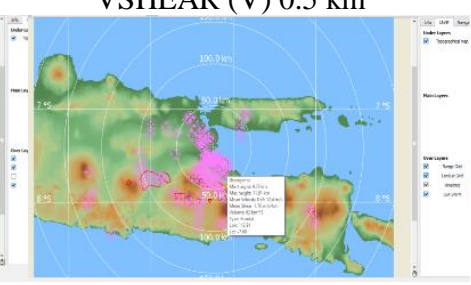

SWI (Vergence)
Figure 4. Radar product at whirl wind occurence in Pasuruan, November 26, 2013

Horizontal wind shear is detected through HSHEAR(V) $0.5 \mathrm{~km}$ worth $14.12 \mathrm{~ms}^{-1} / \mathrm{km}$. While the vertical wind shear is detected through VSHEAR (V) at a height of 0.5 to $5 \mathrm{~km}$ by the value of 
$3.45 \mathrm{~ms}^{-1} / \mathrm{km}$ at $7.625^{\circ} \mathrm{S} 112.866^{\circ} \mathrm{E}$. Divergence in the upper layer shows the updraft and ceonvergent flows while the lower layer shows the downdraft current. On the SWI product, the lower layer convergence occurs at a height of 0.63-1.64 km with an average speed of $12.82 \mathrm{~ms}^{-1}$ difference whereas the divergence of the upper layer at an altitude of $9.79-11.91 \mathrm{~km}$ bythe difference average value of $12.4 \mathrm{~ms}^{-1}$ speed. Description of storm cells through SWI product shows the size of the storm cloud with a value of $3261 \mathrm{~km}^{3}$ volume of cloud, $0.23 \mathrm{~km}$ cloud base height, $13.86 \mathrm{~km}$ cloud tops height, and $58 \mathrm{dBZ}$ maximum reflectivity value at a height of $0.68 \mathrm{~km}$. SWI product showed the existence of isolated severe storm that is verified through the classification of spectral width value Fang 2001. Echo reflectivity patterned bow hook or not observed at CMAX $(\mathrm{Z})$.

\section{Whirl wind Gianyar Bali, March 10, 2015}

Whirl wind that occurred in Bali on March 10, 2015 is based on the observation through Ngurah Rai Meteorological Station and BBMKG Region III cause a dozens of houses and a gas station was heavily damaged. Results of volumetric data processing in the event of a waterspout in Gianyar and Bangli attached in Figure 5.

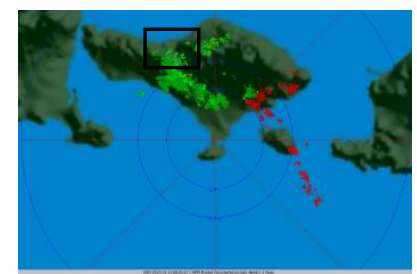

CAPPI(V) $1 \mathrm{KM}$

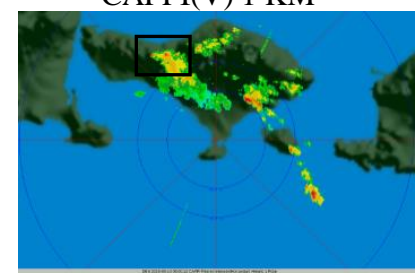

CAPPI (Z) 1 KM

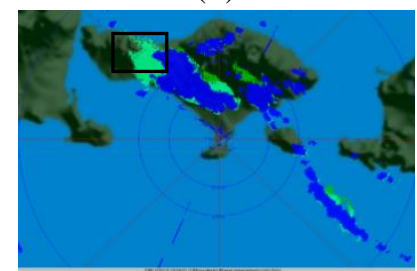

EBASE

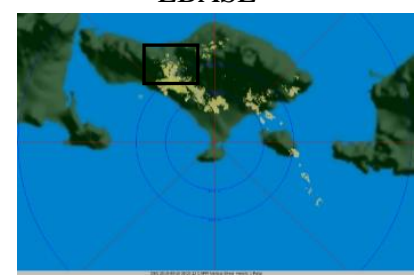

CAPPI(VSHEAR) 1KM

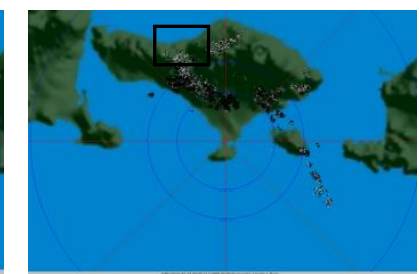

CAPPI (W) 1 KM

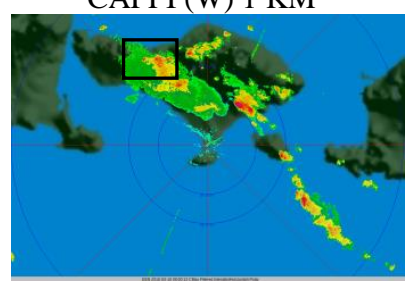

$\operatorname{CMAX}(Z)$

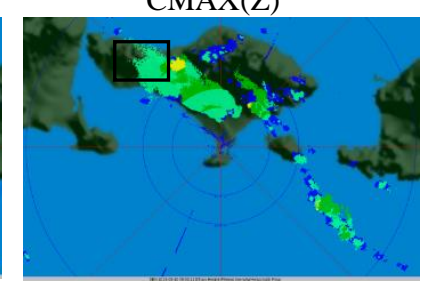

ETOP

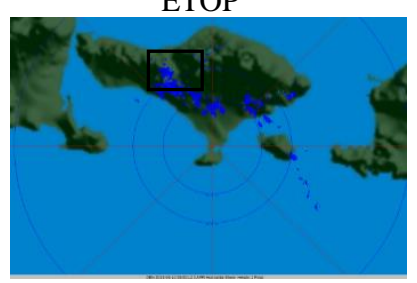

CAPPI(HSHEAR) 1KM
Figure 5. Radar product at whirl wind occurence in Gianyar, Bali, March 10, 2015

Horizontal wind profile shows two echo in the opposite direction and are separated by zero isodop through CAPPI (V) 1 $\mathrm{km}$ with a maximum value of 20.8 knots outbound and inbound maximum of 18.6 knots. Strong turbulence detected by CAPPI
(W) $0.5 \mathrm{~km}$ by the value of $2.7 \mathrm{~ms}^{-1}$ which includes the category of isolated severe storm. That turbulence is reinforced by the presence of horizontal and vertical wind shear at high intensity. Product CAPPI (HSHEAR) $1 \mathrm{~km}$ detect wind shear horizontal amounted to $178.2 \mathrm{knots} / \mathrm{nmi}\left(48.11 \mathrm{~ms}^{-1} / \mathrm{km}\right)$ at coordinates $8.3088^{\circ} \mathrm{S} 114.994{ }^{\circ} \mathrm{E}$ and CAPPI (VSHEAR) $1 \mathrm{~km}$ detect wind shear vertical amounted to $106.2 \mathrm{knots} / \mathrm{nmi}\left(28671 \mathrm{~ms}^{-1} / \mathrm{km}\right)$.

VVP product showed the same thing which the horizontal wind changed direction significantly in the adjacent layers. On the surface layer up to $1 \mathrm{~km}$ height a change of direction is detected three times, the wind from the direction of $230^{\circ}$ at a speed of $18.2 \mathrm{~ms}-1$, a layer 500 meters above by the direction of $290^{\circ}$ at a speed of $7.2 \mathrm{~ms}^{-1}$, and layer $1 \mathrm{~km}$ from the direction of $360^{\circ}$ at a speed of $16.3 \mathrm{~ms}^{-1}$. Fluctuations in wind direction on the adjacent layers indicates the rotation in accordance observations of CAPPI (V) $1 \mathrm{~km}$. Description of the horizontal wind at a height of $2-3 \mathrm{~km}$ showed the dominance of updraft by maximum of $128 \mathrm{~ms}^{-1}$ at an altitude of $2 \mathrm{~km}$, and the dominance of downdraft at a height below $2 \mathrm{~km}$ to the surface reaches the maximum value of $425 \mathrm{~ms}^{-1}$.

Divergences in the layer $1 \mathrm{~km}$ worth $2,644 \times 10^{-4} \mathrm{~s}^{-1}$ (divergent) and a layer $0.5 \mathrm{~km}$ worth $-0337 \times 10^{-4} \mathrm{~s}^{-1}$ (convergent). Two opposing values divergence reinforces the results of the analysis of the existence of the rotation on the product CAPPI (V) $1 \mathrm{~km}$. The cell structure described storm clouds with the cloud base height of $0.7 \mathrm{~km}$ on EBASE products and cloud tops height of $10.7 \mathrm{~km}$ on ETOPS products. The maximum reflectivity value at CMAX products $(\mathrm{Z})$ is worth $53 \mathrm{dBZ}$. Bow echo pattern and hook echo is not detected on the product reflectivity. Strom Products Track and SSA describe storm cell core lies at a height of $0.66 \mathrm{~km}$ with a reflectivity of $46.5 \mathrm{dBZ}$.

\section{Whirl wind Sidoarjo, March 9, 2014}

Whirl wind occurred in the Ketekan Village, Taman Sub District and Bungurase Village, Waru Sub District at coordinates $7351^{\circ} \mathrm{S} 112.769^{\circ} \mathrm{E}$ causing 19 house damaged in District Waru and 185 houses damaged in the Taman Sub District. Results of volumetric data processing in this case contained in Figure 6.

CAPPI (V) $1 \mathrm{~km}$ product analysis detect low-level damaging winds patterns and the rotation of the two radial velocity echo opposite dirrection with a $-3.2 \mathrm{~ms}^{-1}$ maximum inbound and 4.76 $\mathrm{ms}^{-1}$ maximum outbound and the maximum value of outbound at an altitude of $0.5 \mathrm{~km}$ reaches $5.54 \mathrm{~ms}-1$.

The rotation also detected through HWIND product $(\mathrm{V})$ of 0.5 $\mathrm{km}$ with a speed of 5-10 knots. Strong turbulence associated with the rotation indicated through CAPPI (W) $0.5 \mathrm{~km}$ and 1 $\mathrm{km}$ with a maximum value of $2.05 \mathrm{~ms}^{-1}$ and $1.85 \mathrm{~ms}^{-1}$. The value of maximum horizontal wind shear at an altitude of 0.5 $\mathrm{km}$ through HSHEAR(V) worth $11.61 \mathrm{~ms}-1 / \mathrm{km}$ maximum value at $7.306^{\circ} \mathrm{S}$ and $112488^{\circ} \mathrm{E}$, and the values of vertical wind shear at a height of $0.5-5 \mathrm{~km}$ worth $1.71 \mathrm{~ms}^{-1} / \mathrm{km}$ through VSHEAR(V) at coordinates $7.501^{\circ} \mathrm{S} 112.727^{\circ} \mathrm{E}$.

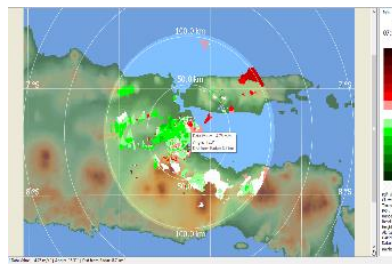

CAPPI (V) $1 \mathrm{~km}$

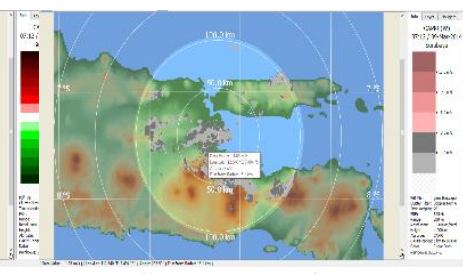

CAPPI (W) $1 \mathrm{~km}$ 

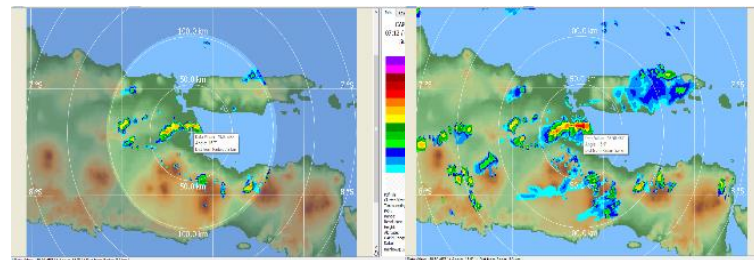

CAPPI (Z) $1 \mathrm{~km}$

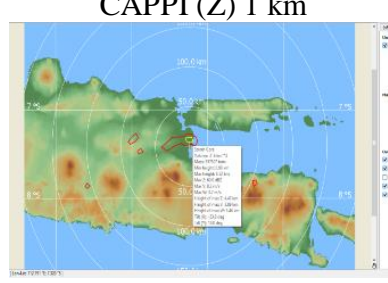

SWI (Storm Core)

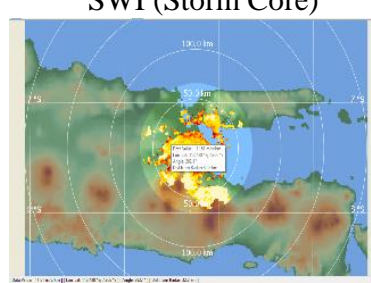

HSHEAR (V) $0.5 \mathrm{~km}$

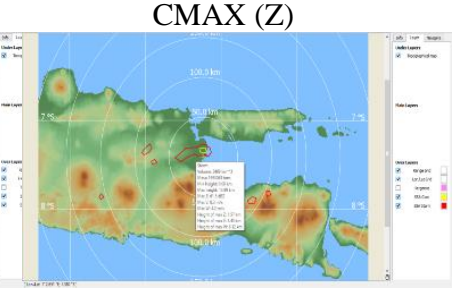

SWI (Storm)

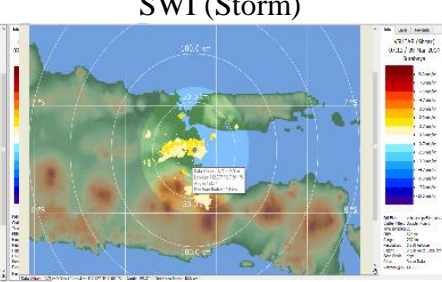

VSHEAR (V) $0.5 \mathrm{~km}$

Figure 6. Radar product at whirl wind occurence Sidoarjo, March 9, 2014

Divergence in the upper layer detected by SWI product shows the updraft flow in the lower layers. Divergences layer height was recorded at 11.66-13.22 km with an average speed of 11.2 $\mathrm{ms}^{-1}$ difference. Storm cell structure described through SWI products with cloud base height reached $0.08 \mathrm{~km}$ and the cloud tops reach $13.99 \mathrm{~km}$. Cloud cell core at an altitude of $0.98 \mathrm{~km}$ with a reflectivity value of $60 \mathrm{dBZ}$. CMAX products $(\mathrm{Z})$ is not recognized bow hook echo and echo pattern. The clouds detected in the form of multicell storm with a reflectivity of 61.5 DBZ.

\section{Whirl wind Gresik, February 20, 2014}

Whirl wind occurred in the village of the District Dooro Cerme at coordinates $7.229^{\circ} \mathrm{S} 112.713^{\circ} \mathrm{E}$ damaged 41 houses by minor damage and seven houses were severely damaged. Results of volumetric data processing in this case contained in Figure 7.

CAPPI (V) $0.5 \mathrm{~km}$ product analysis detect $\mathrm{X}$ cyclonic rotation product analysis in the radial velocity echo with a maximum value of inbound is $-5.02 \mathrm{~ms}^{-1}$ and the maximum outbound is $6.06 \mathrm{~ms}^{-1}$. The rotation occurs at a height of $570 \mathrm{~m}$ through a cross section of products CAPPI (V) $1 \mathrm{~km}$ by the outbound 7.95 $\mathrm{m} / \mathrm{s}$ and inbound $-7.69 \mathrm{~m} / \mathrm{s}$. Verification of rotation indicated by the cyclonic pattern winds at an altitude of $0.5 \mathrm{~km}$ HWIND products.

Product analysis of CAPPI (W) at an altitude of $0.5 \mathrm{~km}$ show a strong turbulence due to the rotation with a spectral width value reaches $2.05 \mathrm{~ms}^{-1}$ at the location of $7.263^{\circ} \mathrm{S}$ and $112.698^{\circ}$ East. Volume cloud clusters detected by SWI products by $2771 \mathrm{~km}^{3}$ at a height of 0.2 till $15.56 \mathrm{~km}$ and reflectivity value by $59 \mathrm{dBZ}$ at $1.31 \mathrm{~km}$ altitude. Horizontal wind shear at an altitude of 0.5 $\mathrm{km}$ has a maximum value of $7.71 \mathrm{~ms}-1 / \mathrm{km}$ that's detected through $\operatorname{HSHEAR}(\mathrm{V})$, and the values of vertical wind shear at a height of $0.5-5 \mathrm{~km}$ has a maximum value of $1.64 \mathrm{~ms}-1 / \mathrm{km}$ through VHEAR( V) at the location of $7.371^{\circ} \mathrm{S}$ and $112.691^{\circ} \mathrm{E}$.

Hook echo pattern and bow echo is not found in the case of this whirl wind.
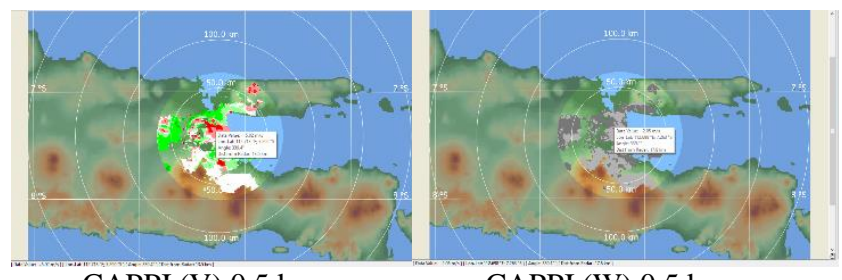

CAPPI (V) $0.5 \mathrm{~km}$

CAPPI (W) $0.5 \mathrm{~km}$
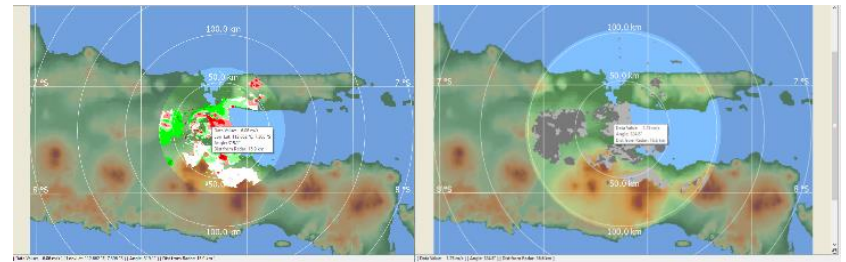

CAPPI (V) $1 \mathrm{~km}$

CAPPI (W) $1 \mathrm{~km}$
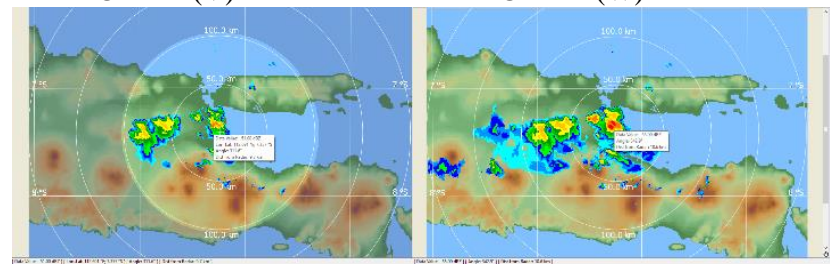

CAPPI (Z) $1 \mathrm{~km}$

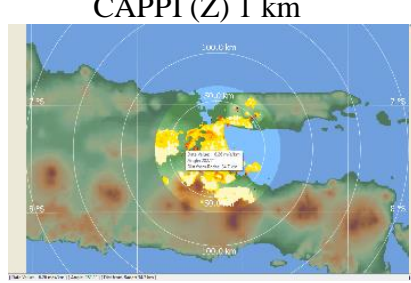

HSHEAR (V) $0.5 \mathrm{~km}$

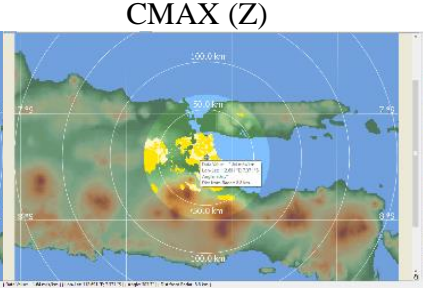

VSHEAR (V) $0.5 \mathrm{~km}$

Figure 7. Radar product at whirl wind occurence Gresik, February 20, 2014

\section{CONCLUSION}

Based on the results of volumetric data processing, whirl wind in Indonesia can be detected properly by BMKG weather radar network. Hook echo or bow echo as whirl wind characteristic pattern was only detected in two of the seven cases. It shows that the detection of whirl winds in Indonesia through product reflectivity is quite difficult. Radial velocity echo analysis results a pattern of rotation on the horizontal winds in $0.5-1$ $\mathrm{km}$ height are found in all cases through CAPPI (V).

Horizontal wind speed has a range of between 3-20 knots, with downdraft intensity reach $425 \mathrm{~ms}^{-1}$ through VVP products. The value of horizontal shear and vertical shear detected at whirl wind events fit the criteria established by Brown in 1977 where the value of the horizontal shear or aazimuthal shear more than $20 \mathrm{~ms}^{-1} / \mathrm{km}$ and a strong vertical shear scale occurred at an altitude of about $1 \mathrm{~km}$. Spectral width values analysis in all cases has range value of $1.85-3.0 \mathrm{~ms}^{-1}$, shows a strong severity of turbulence in the cloud.

The clouds cause the whirl wind are supercell storm and singlecell storm with a very low base height. By paying attention to the results of research, the remote sensing of whirl wind occurrence in Indonesia can be done by analyzing the 
products radial velocity and spectral width, while the reflectivity product is difficult to be a main reference of the whirl wind indication. Existences of rotation in the lower layer, the strength of strong turbulence rotation around the site become a major characteristic whirl wind in Indonesia. By monitoring the products radial velocity and spectral width continuously, early warning to the whirl wind events can be disseminated quickly.

\section{REFERENCE}

Ayudia, S. 2012. Peringatan Dini Kejadian Angin Puting Dengan Pemanfaatan Data Radar (Study Kasus Puting Beliung Di Sidoarjo 26 Desember 2012). Surabaya : BMKG Juanda.

Bohne, K.A, 1982 : General circulation of middle-latitude thunderstorms. In "A Social Scientific and Technology Documentary" (E. Kessler, ed.) pp. 211-247. NOAA, US. Dept. Of Commerce. U.S Govt. Printing Office, Washington, D.C

Christopher Davis, et.al 2004: The Bow echo and MCV Experiment: Observations and Opportunities. Bull. Amer. Meteor. Soc., 85, 1075-1093.

David R. Novak, Brian A. Colle, and Ron McTaggart-Cowan, 2009: The Role of Moist Processes in the Formation and Evolution of Mesoscale Snowbands within the Comma Head of Northeast U.S. Cyclones. Mon. Wea. Rev., 137, 2662-2686.

Fang, Ming and Richard J. Doviak, 2001: Spectrum Width Statistic of Various Phenomena. Oklahoma : Norman. 48-49

Fikroh, Nabilatul. 2013. Analisa Pola Angin Pada Citra Radar saat Kejadian Puting Beliung (Studi Kasus Pangkep, 12 Januari 2013). Jakarta : AMG.

Michael M. French, Howard B. Bluestein, Louis J. Wicker, David C. Dowell, and Matthew R. Kramar, 2009: An Example of the Use of Mobile, Doppler Radar Data for Tornado Verification. Wea. Forecasting, 24, 884-891.

Przybylinski, R.W. 1995. The Bow echo: Observations, Numerical Simulations And Severe Weather Detection Methods. Wea. Forecasting, 10, pp 203-218.

Shirat, Ahmad. 2013. Mendeteksi Puting Beliung Dengan Radar (Studi Kasus Puting Beliung Sidrap Tanggal 24 Februari 2012). Jakarta : AMG.

Siswanto dan Supari. 2011. Identifikasi Kondisi Awal Peristiwa Puting Beliung di Pangkal Pinang. Jakarta : BMKG.

Smith, Richard. 1996. Non-Supercell Tornadoes SR/SSD 96-8 : A Review for Forecaster. NWSFO Memphis : National Weather Service.

Siswanto dan Supari. 2011. Identifikasi Kondisi Awal Peristiwa Puting Beliung di Pangkal Pinang. Jakarta : BMKG.

Ralph J. Donaldson Jr., 1970: Vortex Signature Recognition by a Doppler Radar. J. Appl. Meteor., 9, 661-670.
Rodger A. Brown, Leslie R. Lemon, and Donald W. Burgess, 1978: Tornado Detection by Pulsed Doppler Radar. Mon. Wea. Rev., 106, 29-38.

Roger M. Wakimoto and Brooks E. Martner, 1992: Observations of a Colorado Tornado. Part II: Combined Photogrammetric and Doppler Radar Analysis. Mon. Wea. Rev., 120, 522-543. 